\title{
Prevention of Cardiovascular Disease from an Early Age \\ Senka Mesihović-Dinarević*
}

Policlinic Eurofarm, Sarajevo, Bosnia and Herzegovina

\section{Introduction}

Atherosclerosis is the most frequent disease of arteries characterized by lumen reduction of blood vessel due to local thickening of internal blood vessel by plaque/atheroma [1-3]. It is now one of the leading causes of death in developed countries. Of the ten most common causes of death, diseases of the heart and blood vessels, as a result of atherosclerosis, accounts for six of them. Atherosclerosis begins in childhood, the patient goes a long time without developing symptoms, increasing with age and at about 50 years of age, atherosclerosis seriously begins to threaten health. As a cardiovascular disease, atherosclerosis is an interdisciplinary problem that is treated by: cardiologists, neurologists, epidemiologists, nutritionists etc.

\section{Pathophysiology}

Pathophysiology of this disease concerns damaged cells that line the inner surface of the arteries the endothelium, due to chemical or mechanical damage [4]. Elevated blood cholesterol, smoking, or elevated homocysteine are examples of chemical and mechanical damage to the cells as well as high blood pressure, damage of the catheter during diagnostic procedures or even infections. Hypertension causes the formation of plaque in places where electricity hits the wall of the blood vessel and creates vortices, namely: the aortic arch, bifurcation, arteries, initial parts of the heart or coronary arteries, but also longterm or frequent spasms and immunological mechanisms lead to endothelium damage. The defect site develops inflammation and damaged endothelial cells secrete a variety of substances that attract other cells in the environment, cholesterol, platelets, smooth muscle cells, and by various interactions do accumulate in the walls of arteries. The first stage of the development of atherosclerosis occurs in the form of a "fatty streak." It is totally reversible, which means that with cessation of activities associated with harmful pathogens, endothelial cells can recover completely. However, if exposure to adverse events continues, atherosclerotic plaque grows further narrowing lumen. Consequently, reduced blood flow and tissue oxygen supply become insufficient. In the blood vessel, itself due to reduced elasticity, an increase of blood pressure occurs [5]. Elevated blood pressure can lead to: bursting in blood of the court or its stratification with the formation of aneurysms or plaque, which can calcify and slim down the wall of the vessel with the ability of forming a clot. For atherosclerotic disease, itself plaque composition rather than its size is much more important. Plaque is primarily built of lipids, has a thin cap, hat plaque, and is easier to shoot. If thrombi are formed they can clot arteries. In contrast, larger plaque with a hard cap, which contains less fat, can rarely explode, because it is more stable.

\section{Important risk factors}

The most important risk factors for the development of atherosclerotic disease are: hyperlipidaemia, hypertension, smoking, diabetes, high fibrinogen, male sex at a younger and middle age, menopause in women taking oral contraceptives or hormone replacement therapy only with the presence of other risk factors, excessive weight, increased levels of homocysteine, physical inactivity, heredity and immune response in some diseases $[6,7]$.

\section{Consequences of atherosclerosis}

The Consequences of atherosclerosis are: coronary or ischemic heart disease, especially myocardial infarction, cerebrovascular disease and cerebrovascular accidents ( $80 \%$ of all heart attacks and stroke due to atherosclerosis), the narrowing or blockage of peripheral arteries, carotid arteries, particularly the legs, which can even lead to the development of gangrene [8].

Theprocess ofhypertensionstartsin childhood.Etiopathogenetically it is multifactorial, a possible course and repercussions for health are longstanding and irreversible [9]. Normotension offers important data in contribution to health and increased blood pressure in childhood represents the site for preventive paediatric action. In a study which included 500 children, a correlation of birth weight and blood pressure in the paediatric population was conducted at the Paediatric clinic of Clinical University Centre of Sarajevo, during April-June 2003 [10]. The conclusion was that blood pressure measurement in children could serve for the detection of cardiovascular disease precursors' ages 8 to 9. The correlation of birth weight and systolic pressure exists, but not significantly. The main factors that influence birth weight are: sex (boys were heavier than girls up to $98 \mathrm{~g} \mathrm{p}<0.05$ ), gestational age (preterm were lighter for $600 \mathrm{~g} \mathrm{p}<0.001$ ), and smoking of pregnant mothers (newborns were for $219 \mathrm{~g}$ of lower birth weight in relation to mothers who did not smoke $\mathrm{p}<0.01$ ). Obese participants (important hypertension factor) have increased systolic blood pressure for $5.38 \mathrm{mmHg}$ in relation to those participants with normal blood tension $(\mathrm{p}<0.01)$.

Dislipoproteinaemias and repercussions on the myocardium and blood vessels in the paediatric population, represent an imperative for modern investigation. Basic investigation of lipoproteins, apolipoprotein's metabolism, the biology of the atheromatosus process development in cells, and the role of genetics in the development of disease of coronary arteries is necessary in the field of preventive cardiology. Arteriosclerosis, multifactorial in its etiopathogenesis, course and repercussions, demands action from a team of physicians with the aim of early detection and treatment of dislipoproteinemias and the reduction of the development of risk factors for coronary disease. As atherosclerosis is one of the leading causes of death in society, it represents a responsibility for all paediatricians who should do a screening of lipid levels for all children aged two with a positive family history, as well as children in schools. Dislipoproteinemia is detectable in neonatal age, so the data from Sarajevo's study from 1991, one of the first investigations in the field of preventive cardiology in Europe, points to an elevation of total cholesterol levels, as well as an increase of apo B lipoprotein fraction [11]. In this study, the lipoprotein serum

${ }^{*}$ Corresponding author: Senka Mesihović-Dinarević, Policlinic Eurofarm, Sarajevo, Bosnia and Herzegovina, E-mail: dsenka@bih.net.ba

Received March 27, 2017; Accepted April 17, 2017; Published April 21, 2017

Citation: Mesihović-Dinarevi S (2017) Prevention of Cardiovascular Disease from an Early Age. J Cardiovasc Dis Diagn 5: 268. doi: 10.4172/2329-9517.1000268

Copyright: (c) 2017 Mesihović-Dinarević S. This is an open-access article distributed under the terms of the Creative Commons Attribution License, which permits unrestricted use, distribution, and reproduction in any medium, provided the original author and source are credited. 
level was evaluated in 163 patients without positive family history of cardiovascular risk factors. The control group was comprised of 32 healthy children. In children with cardiovascular disease (congenital heart disease, rhythm disorders, rheumatic fevers), in relation to the control group, an increase of c lipid fraction (triglyceride and LDLP) with a decrease of protective fraction of HDL with statistical significance was proven, adding to increased risk for cardiovascular diseases.

Since there is no specific cure for atherosclerosis, the best way to avoid this disease is prevention. In the United States and Western Europe, where risk factors have been preventively eliminated for a long time, mortality rates "fell" below 50\%. Prevention included avoiding risk factors: instead of obesity subjects should have normal body weight according to sex, age and height, work out or quick walk at least half an hour each day, because $40 \%$ of our bodies are comprised of skeletal muscles that are designed to move [6]. The primary intention of prevention is to preclude the occurrence of risk factors for atherosclerosis, and the secondary is to prevent the development or aggravation of the illness along with the reduction or control of existing risks. Primary prevention should begin as early as possible, even in childhood, creating a healthy diet, eliminating smoking, regular physical activity, which will prevent or at least slow the development of atherosclerosis. In modern medicine, there are a growing number of studies that show that children are overweight, which is certainly an adolescent risk factor for many chronic diseases including: cardiovascular, diabetes type 2 , orthopaedic and psychological illnesses. The epidemic of obesity is one of the most serious health problems of today. During the past two decades, the prevalence of obesity in European countries has increased threefold. Fifty percent of adults today are overweight and a third of the European population is obese. Statistics from the Centre for Disease Control and Prevention $/ \mathrm{CDC} /$ also speak to the tripling of the number of obese people in the last 20 years [12]. Sixteen percent of children and adolescents aged 6-19 years are overweight. Approximately $60 \%$ to $85 \%$ of obese children become obese adults, leading to an earlier and more frequent occurrence of chronic non-communicable disease. Though genetic and hormonal factors are possible causes of children being overweight and obese, excessive food intake and low physical activity are undoubtedly the main reasons for the emergence of obesity. Sitting in front of TV and computer whilst consuming calorie rich fast foods and sweetened beverages create long-term imbalances between the introduction and consumption of energy in the body. The result of this imbalance is being overweight $[13,14]$. Parameters for the most precise estimate of obesity is the body mass index (BMI), which is the ratio of body weight and the square of body height in $\mathrm{kg} / \mathrm{m}^{2}$. Obese people have a BMI greater than the $95^{\text {th }}$ percentile. Factors related to the start of obesity are: a modified diet, reduced physical activity, and increased inactivity. The alarming trend of the expanding epidemic of obesity, particularly an increase in prevalence among young people, presents each community with a problem that has enormous economic and social consequences [1520]. Global measures for the prevention of obesity for the countries of the European region are given in the European Charter of countering Obesity in 2006 [21].

Finding the most effective preventive measures for obesity in each country requires accurate epidemiological data on the number of obese children and adolescents, and their dietary habits and activity, which was one of the goals important research carried out in 20082010 in Canton Sarajevo [14]. The results of this massive study of risk factors for cardiovascular disease (the largest of it's kind in Bosnia and Herzegovina), which was carried out in Canton Sarajevo, from the earliest ages-children in kindergartens, primary and secondary school students and the working age population, practically ages $0-65$, a total of 42,828 respondents were surveyed. Through results from this research, we got the data on: risk factors for cardiovascular disease and atherosclerosis, including the level of physical activity in school environments, and the possibility of prevention, diagnosing and treating to this problem using a modern approach through cognitive behavioural aspects. For the assessment of the nutritional state of children and adolescents we used the body mass index, the degree of nutrition is obtained automatically based on CDC criteria: BMI $<5$ percentile malnutrition. BMI: 5 and 85 percentile normal BW, BMI: 85-95 over nutrition, BMI greater than 95 percentile obesity. The representative sample of students in elementary and secondary schools in Canton Sarajevo were selected via random sample selection. The number of respondents in all elementary (1-8) and secondary (1-4) grades was balanced. Pupils were interviewed in written form. The survey forms were originally designed and included questions about their habits in food intake (frequency, quantity and types) and fluids, and the frequency and intensity of physical activity. The survey forms for primary and secondary schools contained similar questions but were adapted to the age group of specific subjects: lower elementary grades, higher grades of elementary school and secondary school students. Measurements of anthropometric parameters: height and weight, was done for all subjects. Height was measured using a vertical scale in centimetres $(\mathrm{cm})$, and the results are rounded to 0.5 $\mathrm{cm}$. Body weight was measured by electronic floor scales in kilograms $(\mathrm{kg})$, and the results are rounded to $0.5 \mathrm{~kg}$. The research team consisted of two physicians and two graduate nurses. The research was concluded by 2 teams. Subjects voluntarily participated in the survey and measurements the data after being input into the information system was made anonymous from all subjects. The survey and measurements of anthropometric parameters was performed in a total of 3608 students from Canton Sarajevo of which: 2329 were from 9 elementary schools and 1279 from 6 high schools. The results were: about 1/4 of children in the first 4 years are obese, and in higher classes $1 / 5$ of pupils. According to the results of the questioner a majority children do not eat healthy food at home. There is a problem at school concerning eating habits: pupils from lower classes eat food from school and a majority eat food from bakeries (43.31\%). Physical activity was documented in $19.92 \%$ of younger children. In the older groups of pupils there is a greater percentage of pupils who sit in front the TV and PC for up to 2 hours $(30.56 \%)$ they were also sitting during learning which means the majority of the day. A great number of pupils (58.15\%) eats sweets every day between meals (Tables 1-6).

\section{Conclusion}

In Conclusion, the question raised is: what to do about the prevention of cardiovascular disease? Why do schools need to worry about health? As a society, we value good health. Good health is necessary for effective learning. Healthy students become healthy, productive citizens. Schools are the places where we spend most of our youth so we have to initiate a change. The teamwork of an environmental society and new policies are needed. As a priority, we should create a place for physical activity and nutrition in schools; develop funded prevention programs and a systematic approach to the problem. Point to the problem of obesity in an adequate manner, and create partnerships with value to the social community in creating a healthy lifestyle. Schools can provide: quality physical education classes, healthy nutrition campaigns, parenting education, psychosocial education/intervention with nutrition strategy. Prevention is the key! It is necessary to establish dialogue in cardiovascular medicine. Prevention of obesity consists of nutrition conducted according to modern guidelines in relation to the input of: carbohydrates, fats, proteins, vitamins and fluids. It is necessary to 
Citation: Mesihović-Dinarevi S (2017) Prevention of Cardiovascular Disease from an Early Age. J Cardiovasc Dis Diagn 5: 268. doi: 10.4172/23299517.1000268

Page 3 of 4

\begin{tabular}{|c|c|c|c|c|c|c|c|}
\hline \multirow{2}{*}{ School class } & \multirow{2}{*}{$\begin{array}{l}\text { Total number of } \\
\text { students }\end{array}$} & \multirow{2}{*}{$\mathbf{M}$} & \multirow{2}{*}{$\mathbf{F}$} & \multicolumn{4}{|c|}{ BMI classification } \\
\hline & & & & Under Weight (\%) & Normal weight (\%) & Over weight (\%) & Obesity (\%) \\
\hline \multirow{3}{*}{$\begin{array}{c}\text { I-IV } \\
\text { Elementary School }\end{array}$} & \multirow{3}{*}{1077} & \multirow{3}{*}{546} & \multirow{3}{*}{531} & T: 20,86 & $\mathrm{~T}: 55,26$ & $\mathrm{~T}: 12,28$ & $\mathrm{~T}: 11,58$ \\
\hline & & & & M: 7,72 & M: 28,68 & M: 7,47 & M: $\quad 6,77$ \\
\hline & & & & $\mathrm{F}: 13,14$ & $\mathrm{~F}: 26,58$ & $F: 4,81$ & $\mathrm{~F}: \quad 4,81$ \\
\hline \multirow{3}{*}{$\begin{array}{c}\text { V-VIII } \\
\text { Elementary School }\end{array}$} & \multirow{3}{*}{1252} & \multirow{3}{*}{680} & \multirow{3}{*}{572} & $\mathrm{~T}: \quad 9,16$ & T: 69,80 & T: 13,07 & $\mathrm{~T}: 8,00$ \\
\hline & & & & M: 4,65 & M: 37,98 & M: 7,49 & M: 3,69 \\
\hline & & & & $\mathrm{F}: \quad 4,51$ & $\mathrm{~F}: 31,82$ & $\mathrm{~F}: \quad 5,58$ & Ž: 4,31 \\
\hline \multirow{3}{*}{$\begin{array}{c}\text { I-IV } \\
\text { High School }\end{array}$} & \multirow{3}{*}{1279} & \multirow{3}{*}{531} & \multirow{3}{*}{748} & $\mathrm{~T}: 6,76$ & $\mathrm{~T}: 80,43$ & $\mathrm{~T}: 9,55$ & $\mathrm{~T}: 3,24$ \\
\hline & & & & $M: 1,31$ & M: 34,15 & M: 5,18 & M: 1,47 \\
\hline & & & & $F: 5,45$ & $F: 46,28$ & $F: 4,37$ & $\mathrm{~F}: 1,77$ \\
\hline \multirow{3}{*}{ All schools } & \multirow{3}{*}{3608} & \multirow{3}{*}{1757} & \multirow{3}{*}{1851} & T: 12,49 & $\mathrm{~T}: 68,74$ & T: 11,86 & $\mathrm{~T}: 6,86$ \\
\hline & & & & M: 4,63 & M: 33,60 & $\mathrm{M}: \quad 6,71$ & $\mathrm{M}: 1,32$ \\
\hline & & & & $F: 7,86$ & $F: 35,14$ & $F: \quad 5,15$ & $F: 5,54$ \\
\hline
\end{tabular}

Table 1: BMI classification of students according to grades, schools and gender.

\begin{tabular}{|c|c|c|c|c|}
\hline School and class & Homemade sandwich (\%) & Sandwich bought at school (\%) & Food from the bakery (\%) & Snacks (\%) \\
\hline I-IV Elementary School & 30,69 & 44,63 & 5,04 & 17,68 \\
\hline V-VIII Elementary School & 16,57 & 24,62 & 42,67 & 10,96 \\
\hline I-IV High School & 2,70 & 41,09 & 42,01 & 8,89 \\
\hline All schools & 16,65 & 36,78 & 29,90 \\
\hline
\end{tabular}

Table 2: Distribution of the quality nutrition of students in school.

\begin{tabular}{|c|c|c|c|c|}
\hline School class & Water (\%) & Juices (\%) & Milk (\%) & Sodas (\%) \\
\hline I-IV Elementary School & 50,88 & 23,19 & 23,37 & 2,6 \\
\hline V-VIII Elementary School & 54,94 & 21,71 & 12,45 & 11,87 \\
\hline I-IV High School & 49,35 & 16,77 & 13,19 & 20,72 \\
\hline All schools & 51,82 & 20,65 & 16,43 & 11,05 \\
\hline
\end{tabular}

Table 3: Distribution of types of beverages that students drink during the day.

\begin{tabular}{|c|c|c|}
\hline School class & Candys every day (\%) & Sometimes and rarely (\%) \\
\hline I-IV Elementary School & 30,89 & 59,11 \\
\hline V-VIII Elementary School & 64,53 & 33,47 \\
\hline I-IV High School & 80,85 & 19,15 \\
\hline All schools & 58,15 & 31,24 \\
\hline
\end{tabular}

Table 4: Distribution of prevalence of candy consuming.

\begin{tabular}{|c|c|c|c|c|}
\hline $\begin{array}{c}\text { School } \\
\text { class }\end{array}$ & $\begin{array}{c}\text { Every day } \\
\text { activity (\%) }\end{array}$ & $\begin{array}{c}\text { Activity only on } \\
\text { sport class (\%) }\end{array}$ & $\begin{array}{c}\text { Activity 2-3x } \\
\text { per week (\%) }\end{array}$ & $\begin{array}{c}\text { Rarely } \\
\text { (\%) }\end{array}$ \\
\hline $\begin{array}{c}\text { I-IV Elementary } \\
\text { School }\end{array}$ & 19,92 & 39,05 & 40,36 & 0,00 \\
\hline $\begin{array}{c}\text { V-VIII Elementary } \\
\text { School }\end{array}$ & 36,42 & 27,56 & 24,52 & 11,50 \\
\hline I-IV High School & 46,89 & 29,19 & 18,08 & 5,65 \\
\hline All schools & 31,07 & 31,93 & 27,65 & 8,51 \\
\hline
\end{tabular}

Table 5: Distribution of the degree of sports activities.

\begin{tabular}{|c|c|c|c|c|}
\hline School class & $<\mathbf{1}$ hour (\%) & $\mathbf{1 - 2}$ hours (\%) & $\mathbf{2 - 3}$ hours (\%) & $\mathbf{3}$ hours (\%) \\
\hline $\begin{array}{c}\text { I-IV Elementary } \\
\text { School }\end{array}$ & 23,60 & 36,62 & 18,51 & 20,89 \\
\hline $\begin{array}{c}\text { V-VIII Elementary } \\
\text { School }\end{array}$ & 13,81 & 30,56 & 27,74 & 27,96 \\
\hline $\begin{array}{c}\text { I-IV } \\
\text { High School }\end{array}$ & 18,70 & 33,59 & 23,12 & 24,42 \\
\hline
\end{tabular}

Table 6: Distribution of the length of time spent in front of computer and TV.

maintain regular physical activity, both in school and in free time. It is also necessary to promote of continuous education about healthy eating and a healthy lifestyle (activity, not smoking) in all primary and secondary schools in the country, the engagement of teams of family doctors to monitor the nutritional status of school children and youth.

\section{References}

1. Berenson GS, Blonde CV, Faris RP (1979) Cardiovascular disease risk factor variable during the first year of life. Am J Dis Child 133: 1049-57.

2. Berenson GS, Srinivasan SR, Hunter SM, Nicklas TA, Freedman DS, et al. (1989) Risk factors in early life as predictors of adult heart disease: The Bogalusa heart study. Am J Med Sci 298: 141-151.

3. Geer JC, McGill, He Strong JP (1961) The fine structure of human atherosclerotic lesions. Am J Pathol 38: 263-269.

4. Dinarević S (1994) The pathogenesis of atherosclerosis-a review. Brit J Cardiol 67: 241-246.

5. Moore S (1985) Pathogenesis of atherosclerosis. Metabolism 34: 13-16.

6. Dhuper S, Buddhe S, Patel S (2013) Managing cardiovascular risk in overweight children and adolescents. Paediatr Drugs 15: 181-190.

7. Berenson GS, Srinivasan SR, Bao W, Newman WP III, Tracy RE, et al. (1998) Association between multiple cardiovascular risk factors and atherosclerosis in children and young adults. The Bogalusa Heart Study. N Engl J Med 338 : 1650-1656.

8. Newman WP, Freedman DS, Voors AW, Gard PD, Srinivasan SR, et al (1986) Relation of serum lipoprotein levels and systolic blood pressure to early atherosclerosis. The Bogalusa Heart Study. New Eng J Med 314: 138-144.

9. National High Blood Pressure Education Program Working Group on High Blood Pressure in Children and Adolescents (2004) The fourth report on the diagnosis, evaluation, and treatment of high blood pressure in children and adolescents. Paediatrics 114: 555-76.

10. Dinarević S, Mulaosmanović V (2005) Primary prevention of Hypertension in Sarajevo Children: Role of Adiposity. 29th UMEMPS Congress Union of Middle Eastern and Mediterranean Paediatric Societies, pp. 154-156.

11. Dinarević S, Mesihović H, Simeunović S, Zulić I (1994) Dyslipoproteinaemia in Children with Heart Disease. Intercontinental Cardiol 3: 126-9.

12. Centers for Disease Control and Prevention (2015) Over weight and Obesity Data \& Statistics. Accessed on: April 3, 2017.

13. Kapur G, Ahmed M, Pan C, Mitsnefes M, Chiang M, et al. (2010) Secondary hypertension in overweight and stage 1 hypertensive children: A Midwest Paediatric Nephrology Consortium report. J Clin Hypertens 12: 34-39.

14. Dinarević S, Hasanbegović S (2010) Problem of obesity in children and youth in Canton Sarajevo. Pediatr Res 68: 1091.

15. WHO Europe (2007) The challenge of obesity in the WHO European Region and the strategies for response. Copenhagen: WHO Regional Office for Europe. 
Citation: Mesihović-Dinarevi S (2017) Prevention of Cardiovascular Disease from an Early Age. J Cardiovasc Dis Diagn 5: 268. doi: 10.4172/23299517.1000268

Page 4 of 4

16. Daniels SR, Arnett DK, Eckel RH, Gidding SS, Hayman LL, et al. (2005) Overweight in children and adolescents: Pathophysiology, consequences, prevention and treatment. Circulation 111: 1999-2012.

17. Berenson GS, Wittingly WA, Tracy RE, Newman WP, Srinivasan SR, et al. (1992) Atherosclerosis of the aorta and coronary arteries and cardiovascular risk factors in persons aged 6 to 30 years and studied at necropsy (The Bogalusa Heart Study). Am J Cardiol 70: 851-858.

18. McNiece KL, Gupta-Malhotra M, Samuels J, Bell C, Garcia K, et al. (2007) National High Blood Pressure Education Program Working Group: Left ventricular hypertrophy in hypertensive adolescents: Analysis of risk by 2004
National High Blood Pressure Education Program Working Group staging criteria. Hypertension 50: 392-5.

19. Torrance B, McGuire KA, Lewanczuk R, McGavock J (2007) Overweight physical activity and high blood pressure in children: a review of the literature. Vasc Health Risk Manag 3: 139-149.

20. Genovesi S, Antolini L, Giussani M, Federico P, Sara G, et al. (2008) Usefulness of waist circumference for the identification of childhood hypertension. J Hypertens 26: 1563-70.

21. http://www.euro.who.int/document/E89567.pdf 15-17 November 2006. 